\title{
末梢静脈循環動態の麻酔学的諸因子による変化に関する 臨床的研究（無侵襲計測法による無麻酔下実験）
}

百合野公庸* 大石一男* 松岡晴江*

渡辺誠之* 田山文隆* 無敵剛介*

\begin{abstract}
要旨 安静仰臥位健康成人男子 (平均年齢19.93 1.59歳)における呼吸運動時の右橈側皮静脈血流 量（平均 $25.26 \pm 4.73(\mathrm{SE}) \mathrm{m} \ell / \mathrm{min}$ ) 変化の程度を追及するため Valsalva および Müller maneuver を行ない，それをもとに針通電および $3.5 \%$ 修飾ゼラチン溶液 $0.4 \mathrm{~m} \ell / \mathrm{kg} / \mathrm{min}$ の急速輸液時の経時的 変化を両側手掌深部体温, 心拍数, 血圧の変化と共に無麻酔下に無侵襲計測法を用いて比較検討し た。橈側皮静脈血流の変化傾向は安静吸気時減少, 呼気時に増加を示し, Valsalva maneuver およ び Müller maneuver 時には減少，また針通電刺激（合谷一手三里，1.4Hz，2〜6V，15分間）時に は, 刺激直後減少, その後刺激前值を越えて増加を示し, 一方, 急速輸液でも橈側皮静脈血流量は

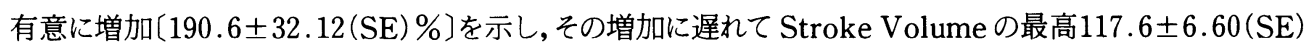
\%の増加を示した. 以上の研究結果より針通電による末梢静脈循環増加の要因の一つとして Stroke Volume の増加が考えられ, その程度は $3.5 \%$ 修飾ゼラチン溶液 $0.4 \mathrm{~m} \ell / \mathrm{kg} / \mathrm{min} 10$ 分間投与後の循環動 態変化に相当するものと考えられた。
\end{abstract}

呼吸 ${ }^{1)}$ 針通電の循環動態 ${ }^{2} に$ 及ほす効果につ いての研究は, 従来侵襲的方法によるものが多 く，そのため種々の要因の関与により，その効 果について適確な判定を得ることが困難であっ た、今回，われわれは種々の非侵襲的方法を用 いて, 呼吸の末梢静脈循環動態に及ほすす影響に ついて追究し, その研究成果をもとに針通電に よる末梢循環動態の変化を経時的に追究した. さらに針通電効果を $3.5 \%$ 修飾ゼラチン溶液

*久留米大学医学部麻酔学教室

受理日 1986.3 .22
(Haemaccel $\left.{ }^{\circledR}\right)$ の急速輸液を行なった場合の変 化の度合と比較検討するとともに針通電効果の 循環動態に及ぼす機序についても検討を加えた。

\section{対象と方法}

神経・呼吸器疾患および明らかな心血管性病 変を有しない17〜23歳までの健康な男性14例を 対象とした. 平均年齢は19.93歳であった. 測定 項目および測定機器は表1-1に示した.表1-2に 示す如く対象を Control group(10名), Valsalva -Müller group ( 3 名), 針通電 (EAP) group (11名), 急速輸液 group( 8 名)の 4 群に分けた. 
表1-1

[測定項目および測定機器]

\begin{tabular}{|c|c|}
\hline 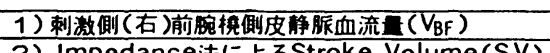 & 1) ALVAR社超音波ドップラ-血流計ECHOVAR8 \\
\hline $\begin{array}{l}\text { 2) Impedance法によるStroke Volume(SV) } \\
\text { 3) Heart Rate(HR) }\end{array}$ & $\begin{array}{l}2,3) \text { Bomed社 Noni nvasive Cont inuous } \\
\text { Cardiac Out Put Monitor }\end{array}$ \\
\hline 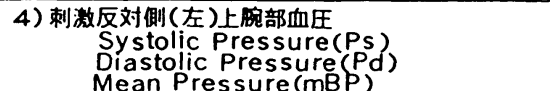 & $\begin{array}{l}\text { 4) MEDEC社血压連続監視装置 } \\
\text { Universal, }\end{array}$ \\
\hline
\end{tabular}

\section{表1-2}

[研究方法] 1) Vals alva.Mülle
Group

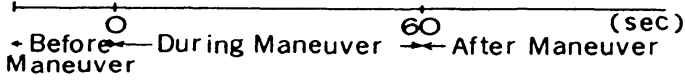
2) Control Group
3) EAP Group 刺激条件 $\begin{array}{r}1.4 \mathrm{~Hz} \\ 2 \sim 6 \mathrm{~V}\end{array}$ (得気)
4) Rapid Infusion Group

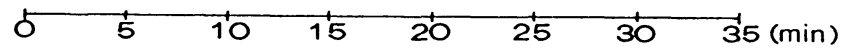

$\underset{\text { EAP }}{\text { Before During EAP } \stackrel{15}{\longleftarrow} \text { After EAP }}$ $0(\mathrm{~min})$
[研究対象]

$$
\underset{\text { Transfusion }}{\stackrel{\text { Before }}{\mathrm{O}} \text { During }} \underset{\text { Transfusion }}{\stackrel{10}{1} \text { After Transfusion }} \stackrel{4}{\longrightarrow}(\mathrm{min})
$$
対象は神释・呼吸器疾患およひ明らかな心血管性病変を有しない17～23才 (平均年令 19.93 11.59)
までの健康な男性14名である

$\begin{array}{lr}\text { Valsalva-Müller Group } & 3 \text { 名 } \\ \text { Control Group } & 1 \text { O名 } \\ \text { EAP Group } & 1 \text { 名 } \\ \text { Haemaccel Group } & 8 \text { 名 }\end{array}$

i ) Control group：安静仰臥状態のまま, 各 項目の值の経時的変化を 5 分間隔で 35 分間観察 したもの.

ii ) Valsalva-Müller group : 安静仰臥状態 で 1 回換気量 $\left(\mathrm{V}_{\mathrm{T}}\right)$ の大きさの程度を変えた呼 吸をさせ, その時の各項目の数值を追究し, そ の後 Maneuver 前值をコントロールとして60秒 間の Valsalva および Müller maneuver を実施 させ, maneuver 1 分後までの 10 秒毎に各数值を 追究した。

iii）針通電 (EAP) group：刺激前值をコント ロールとして15分間針通電刺激を行ない針刺激 開始より40分間の各項目についての数値の変化 を 5 分毎に追究した。

iv）急速輸液 group：輸液前值をコントロー ルとして, $3.5 \%$ 修飾ゼラチン溶液を 10 分間急速
輸液し，輸液開始後より40分間の各項目につい ての数值の変化を 5 分毎に追究した，実験室は 室温 $27 \sim 28^{\circ} \mathrm{C}$, 湿度 $63 \sim 67 \%$ とし, 実験中の室 温の変化は $1^{\circ} \mathrm{C}$ 以内とした。このような条件下で, 被験者をべッドに安静仰臥させたあと, 各項目 で安定した数值が得られた段階で各 group の測 定を開始した。針刺激には，ステンレス製日本 針（寸 3-3番）を用い, 合谷一手三里において, 被験者が痛みを訴えることなく得気をえた場所 で針を固定し, Neurometer NAF 型にて1.4Hz, $2 \sim 6 \mathrm{~V}$ の強さで通電刺激を行ない, 刺激中は Muscle twitch が認められる状態とした。また， $3.5 \%$ 修飾ゼラチン溶液はほほ体温と同じに Warmer Coil を通じて加温し, 輸液した。輸液 量はわれわれの教室で検討した結果, $0.4 \mathrm{~m} \ell / \mathrm{kg}$ /minとした。 
表 2 Control groupの各測定値 (安静仰臥位)

\begin{tabular}{|c|c|c|c|c|c|c|c|c|c|}
\hline & Time & 0 & 5 & 10 & 15 & 20 & 25 & 30 & 35 \\
\hline \multirow{3}{*}{ V.F. (x) } & 平均士SE & 100 & $\begin{array}{r}92.2 \\
\pm \quad 7.27 \\
\end{array}$ & $\begin{array}{r}100.56 \\
\pm \quad 4.04\end{array}$ & $\begin{array}{r}88.2 \\
\pm \quad 5.73 \\
\end{array}$ & $\begin{array}{r}86.1 \\
+\quad 9.63\end{array}$ & $\begin{array}{r}98.4 \\
+10.74 \\
\end{array}$ & $\begin{array}{r}89.22 \\
+\quad 9.05\end{array}$ & $\begin{array}{r}84.6 \\
\pm \quad 5.90 \\
\end{array}$ \\
\hline & Max. & 100 & 123 & 118 & 122 & 146 & 149 & 120 & 106 \\
\hline & Mini. & 100 & 42 & 85 & 62 & 49 & 38 & 33 & 63 \\
\hline \multirow{3}{*}{ S.V. (x) } & 平均 $\pm S E$ & 100 & $\begin{array}{r}101.7 \\
+\quad 3.83 \\
\end{array}$ & $\begin{array}{r}102.1 \\
+\quad 3.06 \\
\end{array}$ & $\begin{array}{r}98.7 \\
\pm \quad 8.41\end{array}$ & $\begin{array}{r}101.4 \\
+10.20 \\
\end{array}$ & $\begin{array}{r}96.2 \\
\pm 10.28 \\
\end{array}$ & $\begin{array}{r}100.67 \\
+14.72\end{array}$ & $\begin{array}{r}100.4 \\
\pm \quad 9.29\end{array}$ \\
\hline & & 100 & 121 & 111 & 111 & 119 & 105 & 118 & 110 \\
\hline & Mini. & 100 & 82 & 84 & 83 & 81 & 79 & 70 & 87 \\
\hline \multirow{3}{*}{ H. R. (x) } & 平均 $\mathrm{S} S E$ & 100 & $\begin{array}{r}98.6 \\
\pm \quad 3.63 \\
\end{array}$ & $\begin{array}{r}97.0 \\
\pm \quad 3.11\end{array}$ & $\begin{array}{r}99.1 \\
\pm 3.45 \\
\end{array}$ & $\begin{array}{r}94.7 \\
\pm \quad 3.44 \\
\end{array}$ & $\begin{array}{r}100.7 \\
\pm \quad 3.57\end{array}$ & $\begin{array}{r}98.11 \\
\pm \quad 6.10\end{array}$ & $\begin{array}{r}96.6 \\
+\quad 4.79 \\
\end{array}$ \\
\hline & $\operatorname{Max}$. & 100 & 122 & 115 & 124 & 117 & 124 & 144 & 120 \\
\hline & Mini. & 100 & 84 & 83 & 88 & 77 & 71 & 75 & 79 \\
\hline \multirow{3}{*}{$\begin{array}{c}\text { Systolic } \\
\text { P. }\end{array}$} & 平均 $\pm S E$ & 100 & $\begin{array}{r}100.0 \\
\pm \quad 4.01\end{array}$ & $\begin{array}{r}100.4 \\
\pm 2.76 \\
\end{array}$ & $\begin{array}{r}102.7 \\
+\quad 3.80 \\
\end{array}$ & $\begin{array}{r}102.5 \\
\pm \quad 2.87 \\
\end{array}$ & $\begin{array}{r}100.9 \\
\pm \quad 3.40 \\
\end{array}$ & $\begin{array}{r}100.11 \\
\pm \quad 3.95 \\
\end{array}$ & $\begin{array}{r}95.6 \\
\pm 2.07 \\
\end{array}$ \\
\hline & $\operatorname{Max}$. & 100 & 130 & 118 & 134 & 122 & 125 & 127 & 106 \\
\hline & Mini. & 100 & 87 & 91 & 90 & 91 & 85 & 90 & 88 \\
\hline \multirow{3}{*}{$\begin{array}{c}\text { Diastolic } \\
P .\end{array}$} & 平均士 $\mathrm{SE}$ & 100 & $\begin{array}{r}96.3 \\
\pm \quad 5.55 \\
\end{array}$ & $\begin{array}{r}100.1 \\
\pm \quad 3.48 \\
\end{array}$ & $\begin{array}{r}99.2 \\
\pm \quad 3.47 \\
\end{array}$ & $\begin{array}{r}102.1 \\
\pm \quad 2.50 \\
\end{array}$ & $\begin{array}{r}105.6 \\
\pm \quad 6.12 \\
\end{array}$ & $\begin{array}{r}103.77 \\
\pm 2.96\end{array}$ & $\begin{array}{r}109.6 \\
\pm \quad 4.13 \\
\end{array}$ \\
\hline & Max. & 100 & 110 & 127 & 111 & 119 & 153 & 121 & 127 \\
\hline & Mini. & 100 & 53 & 91 & 73 & 96 & 90 & 88 & 95 \\
\hline
\end{tabular}

\section{結 果}

\section{i ) Control group : 安静仰臥状態における各} 測定項目の数值を表 2 に示した。橈側皮静脈血 流量の変動幅は大きく最大 149 ～33\%であるが, 平均 $84.8 \pm 5.90(\mathrm{SE}) \%$, 血圧は $95.6 \pm 2.07 \%$, HR は $94.7 \pm 3.44 \%$ に止る。

ii) Valsalva-Müller group (呼吸の橈側皮静 脈血流に与える影響)：平時よりやや大きめの自 発呼吸時の超音波ドップラー法による橈側皮静 脈血流の変化を示したのが図1-1である.流速を 示す波高は吸気開始より吸気終末にかけて次第 に低くなり，呼気開始により次第に増高した。 この症例では呼気開始時にくらべ, 吸気終末時 では約14\%の減少を示した.図1-2に示したのが, 急速深呼吸時の静脈血流の変化で, 前記の変化 と同様の経過を示したが，その程度はさらに大 きく，この症例では約 $53 \%$ の減少を示した。図
1-3 は短時間の Valsalva maneuver を施行した 例で Maneuver 直後より静脈血流は著しく減少 し, Maneuver 解除後, 再びもとの值へ復帰して いる.これをさらに別の症例で橈側皮静脈血流 量, Cardiac output, 血圧, 心拍数の各項目に ついてみたのが図1-4で, Maneuver 開始後, 静 脈血流量および Cardiac output とも大幅な減少 を示し，心拍数はやや増加がみられた，同一症 例で Müller maneuver を行なったのが，図1-5 で静脈血流量およびCardiac output の減少度は Valsalva maneuver にくらべ小さいものであっ た. 上記の変化をV Valsalva-Müller group 全体 でみたものが図 2 でValsalva maneuver 施行群 (図2-1)では, Maneuver 直後より静脈血流量お よび Cardiac outputの著明な減少がみられ，心 拍数はやや増加し, Maneuver 解除後は次第にコ ントロール值へ復帰した. Müller maneuver(図 2-2)では, 静脈血流量および Cardiac output の 
減少は Valsalva 例にくらべ少ないものであった。

以上述べた呼吸による橈側皮静脈血流への影 響を考慮の上，できるだけ呼吸による影響を少 なくし, EAP group, 急速輸液 group の実験を 行なった.

iii）針通電 (EAP) group：図3-1に示すよう に静脈血流量は, 針通電刺激開始直後より一過
性に減少し，次第に刺激前値を越えて増加し， 25分後に最大值に達した後, 再び刺激前值へ復 帰した。これらの症例は同時に最高 $16 \%$ の Stroke Volume の増加が認められた。一部の症例で手掌 深部体温をモニターした結果, 静脈血流量の変 化に遅れて静脈血流とほぼ同様の経過をたどっ た. 図3-2 に示したのが血圧の変化であるが, 拡

図1-1

図1-2

Effect of Spontaneous Respitation

36y. S. $65 \mathrm{~kg} . \quad 1986.4 .3$.
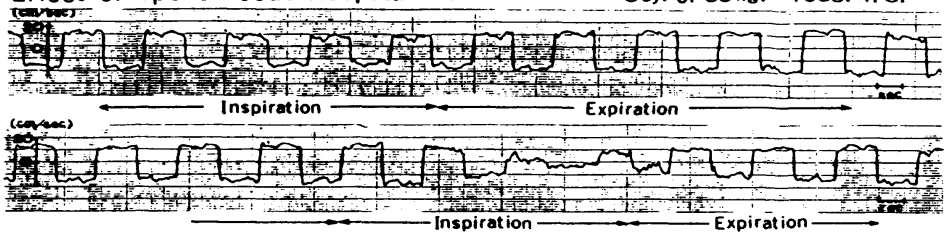

図1-3

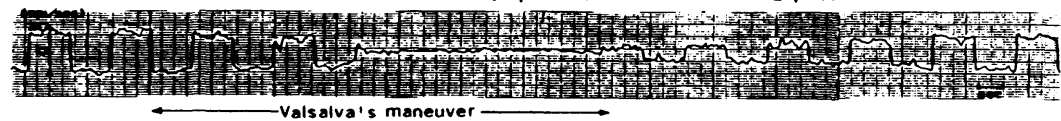

図1-4

(A)

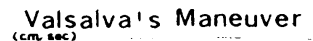

21 y. ิ. $62 \mathrm{~kg} . \quad 1985.9 .18$.

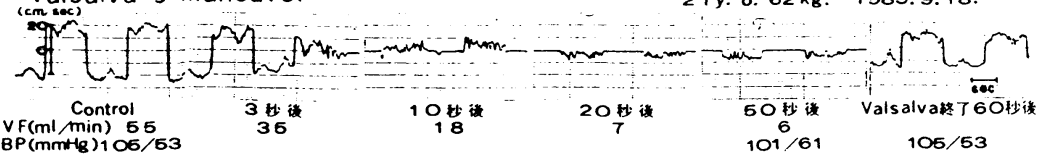

(B)

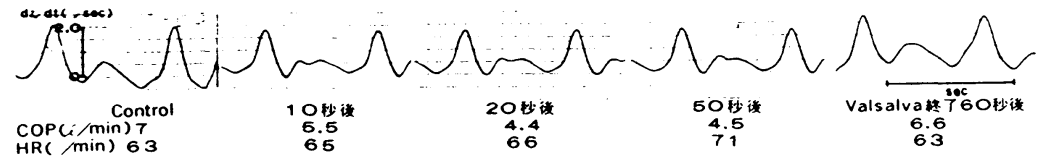

図1-5

(A)

(min) 63

65

66

Müller's Maneuver

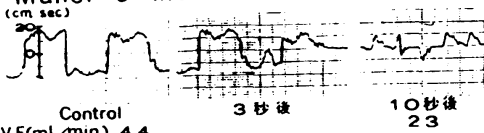

$\mathrm{VF}(\mathrm{m} / \mathrm{\text {Control }}$ min 44

3 w
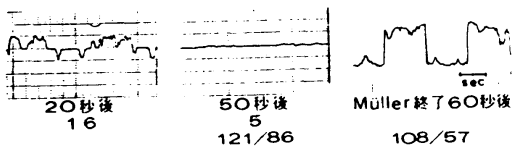

(B)

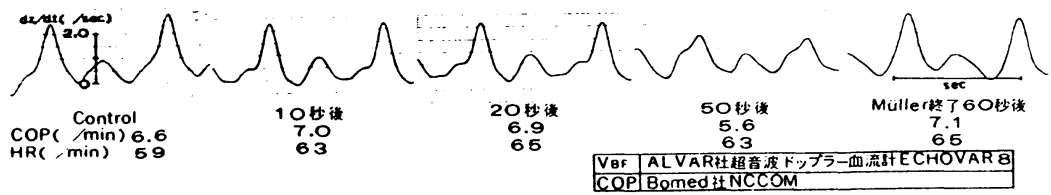

○図 1 - 1 〜 3 及゙゙図 1-4(A), 図 1-5(A) は超音波ドップラー血流計による暁側皮静脈 血流波形の変化を示す.

図 $1-1$ : 安静呼吸時 1 回換気量の約 3 倍の 1 回換気量自発呼吸時

図 $1-2$ : 安静呼吸時 1 回換気量の約 4 倍の 1 回換気量急速深呼吸時

図 1-3:短時間のValsalva maneuver施行時の全経過を連続的に示したもの

図 1-4(A)：60秒間の Valsalva maneuver施行時

図 1-5(A)：60秒間の Müller maneuver施行時

○図 1-4 (B) 及び図 1-5 (B) は非観血連続心拍出量モニターのインピーダンス波形を示す.

(）結果説明は本文中に記す。 
張期圧はやや上昇傾向を示したものの，収縮期 圧は有意な変化はなく,図3-3に示した心拍数も 有意な変化は認められなかった。

iv）急速輸液 group：図4-1に示すように静 脈血流量は急速輸液開始より増加が認められ， 投与開始 10 分後に最高に達し，以後次第に減少 傾向を示した。またこれらの症例では，最高17 \%の Stroke Volume の増加が認められ, 輸液後
しばらくして増加を始め，静脈血流量の最高点 にやや遅れて最高に達した。一部の症例で手掌 深部体温を測定した結果，静脈血流の変化にや や遅れて，ほほ同様の経過をたどって上昇を示 した. 図4-2 および図4-3 は血圧, 心拍数の変化 を示したものであるが，有意な変化はみられな かった.

図2-1

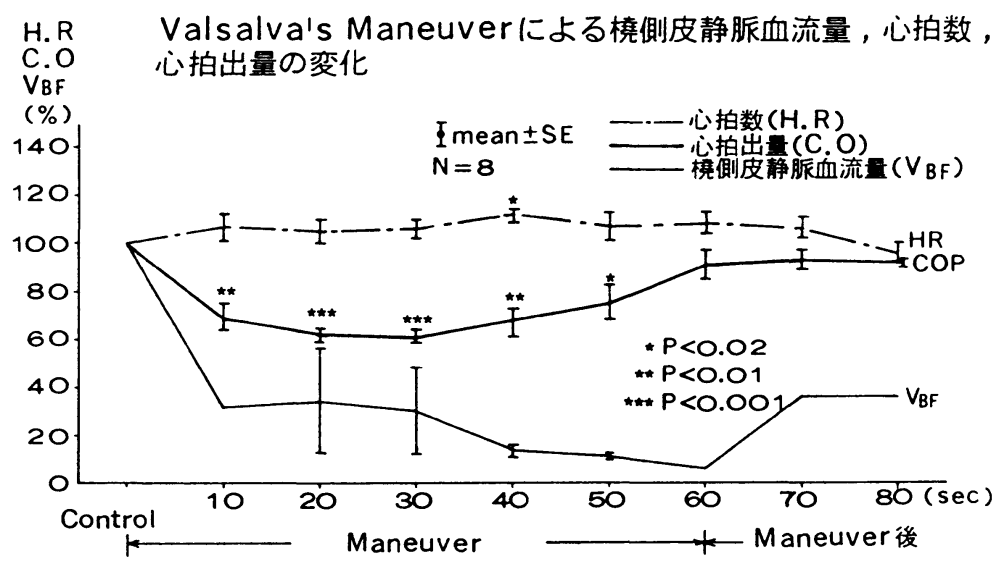

図2-2

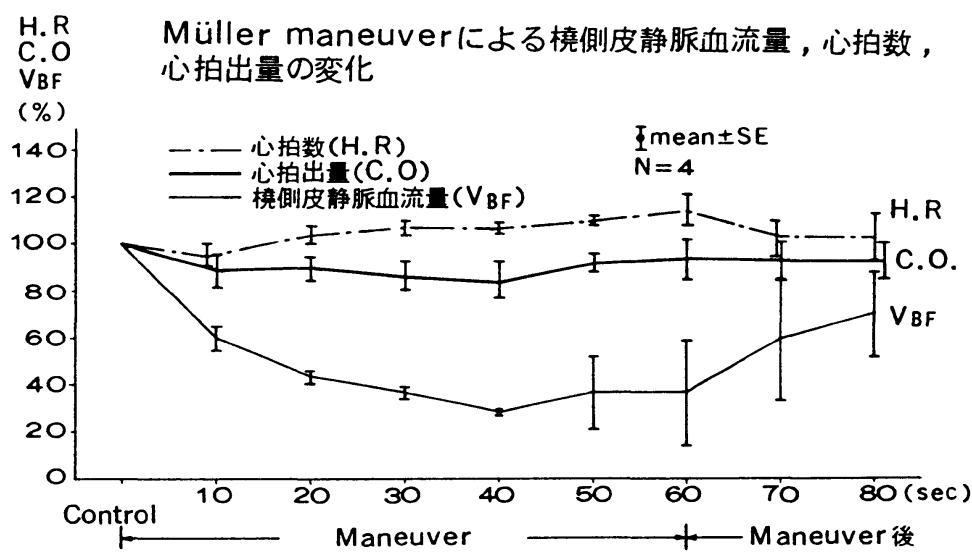


図3-1

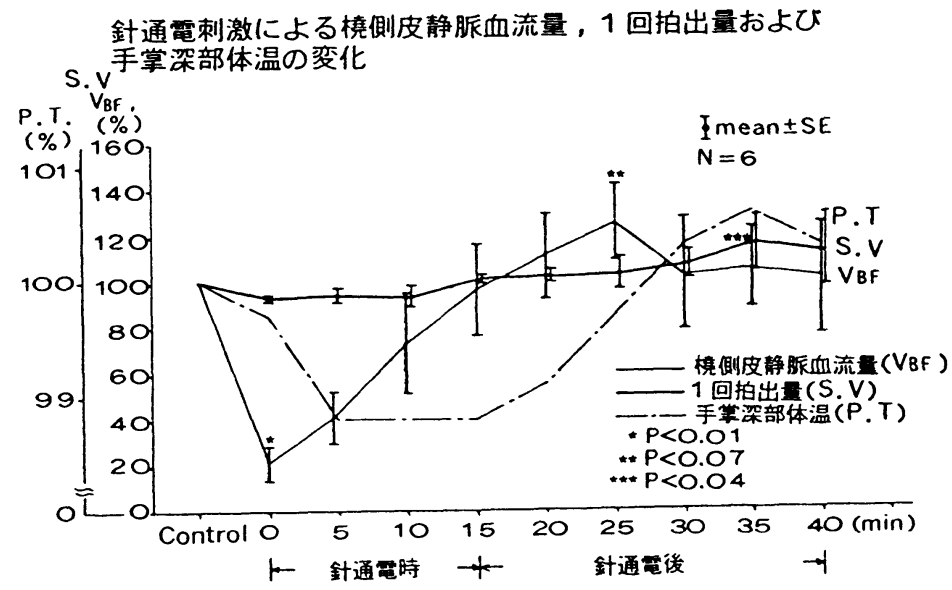

図3-3 Pd,Ps 針通電刺激による血圧の変化

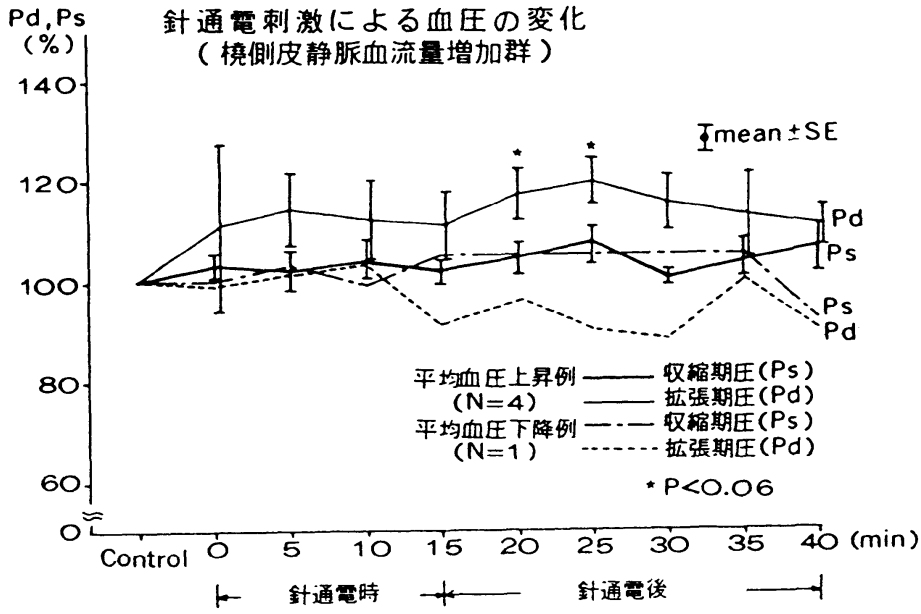

図3-2

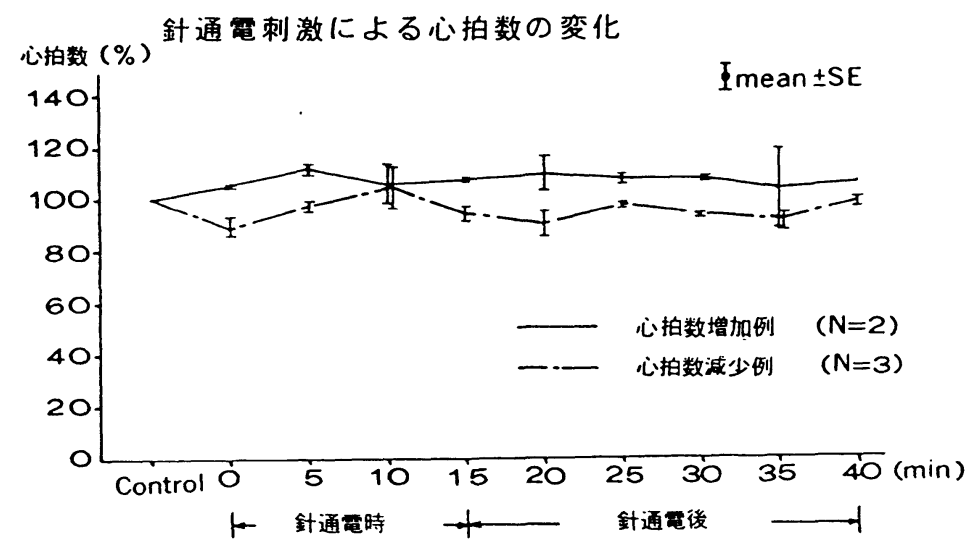


図4-1

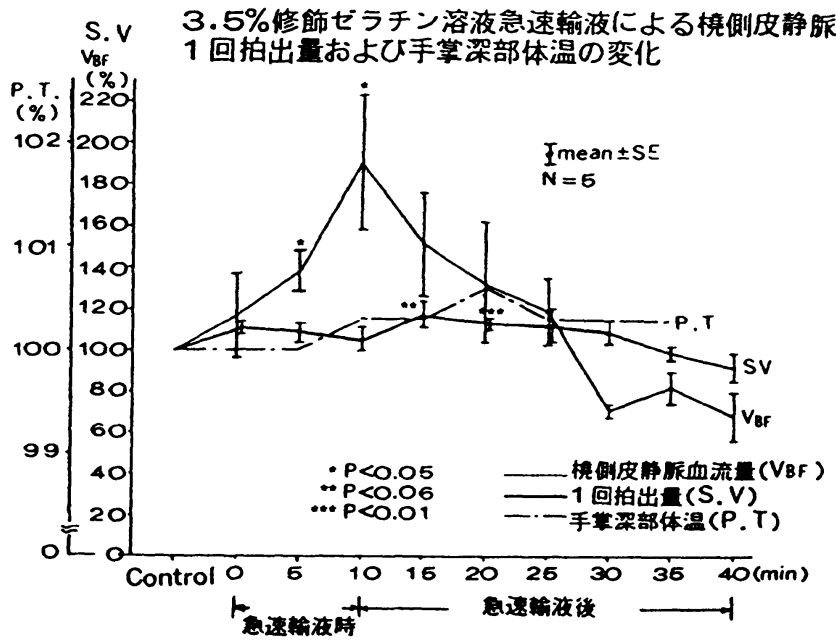

図4-2

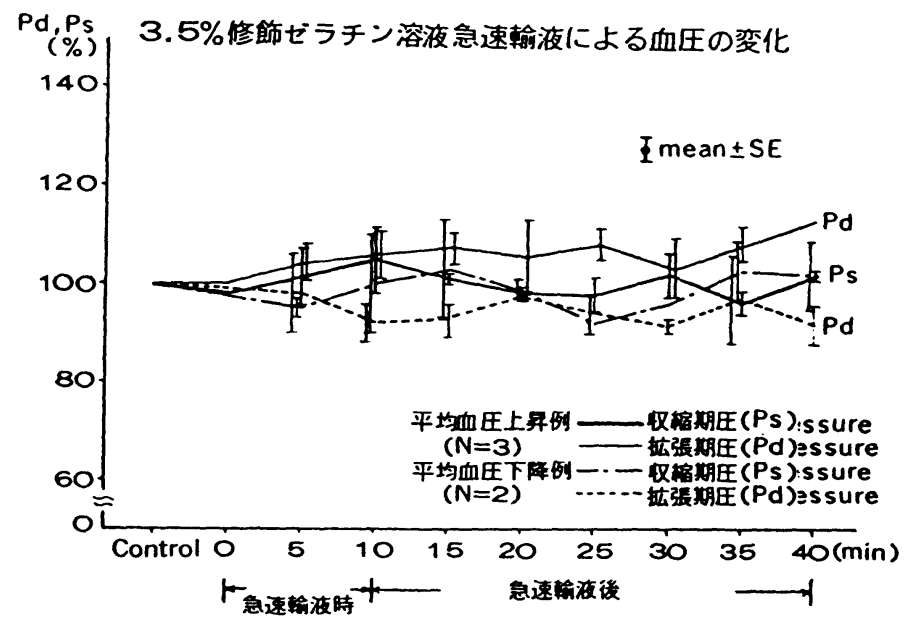

図4-3

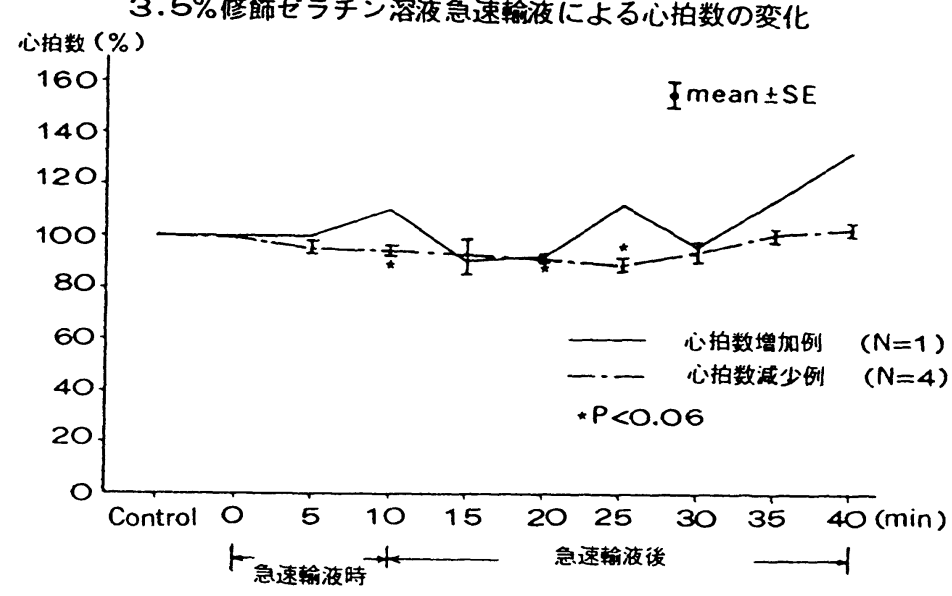




\section{考 察}

1859年 Donder, F.C. ${ }^{3)}$ にって吸気時胸腔内 圧下降により静脈還流は増加するという Respiratory pump の概念が提唱されて以来, 呼吸運動 の静脈還流に対する影響についてさまざまな意 見が提示されてきた. 山元ら4)は, 開胸犬を用い 循環動態パラメーター測定の実験設置を行なっ てから, 閉胸後自発呼吸下の横隔膜上下の下大 静脈流量をMTS 電磁流量計を用いて測定した 結果，吸気時に胸部下大静脈ではその径ととも に流量は減少し，腹部下大静脈では増加すると 報告している。また，Brecher, G.A.ら5)もまた， 吸気時胸腔内圧陰圧の増強により静脈還流量は 増加し, 呼気時胸腔内圧の上昇により還流量は 減少すると報告している。一方, Willeput, R.ら ${ }^{6)}$ はヒトの下肢静脈還流を femoral veinにおいて 超音波ドップラー血流計を用いて測定した結果， 吸気時に下肢からの静脈還流は減少したと報告 している。ところで静脈系は動脈系と異なり， 末梢から中枢に到るまで一様の静脈還流動態を 保っているわけではない。森岡ら7は静脈還流動 態を理解するのに生体組織コンパートメントの 概念を提唱し，形・位置は変っても短時間内に 容量のあまり変らない限られた区域を水力学的 コンパートメントと考え, 生体は胸腔, 腹腔, 筋肉などの各種コンパートメントの集合である とした. thoracic pumpの考えは胸腔がコンパ ートメントであることを容認するものであり， 胸腔および腹腔はそれぞれの水力学的コンパー 卜を成し，呼吸に際し，胸腔と腹腔が逆相の圧 変化を示すため, Willeput, R. などの実験結果の ように femoral vein における吸気時の静脈血流 の減少, 呼気時の増加という呼吸運動と静脈血 流の増減において, Brecher, G.A. らの報告と反
対の結果がでるものと考えられる。つまり，そ れぞれのコンパートメントにおいて条件が異な るため, 測定部位によって静脈血流量の増減が 異なるものと考えられる.また阪口鼻は下肢静脈 を表在静脈，深部静脈およびこれらを連結する 交通枝に機能的に分類し, Almen, T.ら ${ }^{9)}$ は腓腸 筋運動時の連続静脈造影を行い, 媣部静脈の吸 い込み現象によって表在静脈が空虚になる現象 を観察している．今回，われわれが行なった橈 側皮静脈血流量の吸気時減少についても, 胸腔 コンパートメントに対しての上肢コンパートメ ント，さらに上肢コンパートメントの中でも静 脈還流機構上表在静脈と深部静脈とをそれぞれ 個々のコンパートメントでの存在と考えると, 胸腔内大静脈の吸気時静脈還流増大にともない, 上肢深部コンパートメント静脈流量は増加する 可能性が考えられる。すなわち，上肢深部静脈 血流量はむしろ増加し, 表在静脈血が吸引され るため，われわれが測定した表在静脈である橈 側皮静脈血流量の減少結果として表われた可能 性が考えられる。尚，皮膚静脈は交感神経によ り収縮性の緊張支配を受けており，深呼吸およ びValsalva maneuverにより反射性血管収縮が 起こることが知られており，この効果の影響も 考慮されるべきであろう.EAP group における 橈側皮静脈血流量, Stroke Volume, 手掌深部 体温の経時的変化は程度の差こそあれ, 針通電 刺激により一過性に下降し, 通電終了後, 刺激 前值を越えて有意な上昇を示している。針通電 時の特定部位の深部体温の一過性の下降は久住 $ら^{11)}$ は鼻部皮膚温において, Ernst, M.ら ${ }^{12)}$ は手, 足の皮膚温において報告しており，また久住ら は下降から上昇へ転ずるパターンには，刺激終 了後 5 分間を経ても刺激前値へ回復しないもの, 刺激終了後 5 分間で刺激前值まで回復するもの, 
針通電刺激中に回復傾向を示し，刺激中に刺激 前値以上になるものとに分けており，われわれ が針通電により深部体温および橈側皮静脈血流 量を測定した際にも，刺激中に刺激前值を上回 って上昇するものと, 刺激後に上昇するものと が認められた，久住らは，針通電による鼻部皮 膚温の下降減少は針通電刺激側の星状神経節ブ ロックによりみられなくなることから，皮膚温 の下降は交感神経の関与が示唆され, 刺激後も 下降がしばらく持続する例もあることから，こ の反応は直接交感神経を刺激したというょりは, むしろ中枢の調節系を介しての反応と考えた。 下降後の刺激前值を越えた上昇については，そ の機序は判然としない部分が多い.Ernst, M.ら は経穴には，組織学的に高い密度で筋紡錘が存 在するという特徵に注目し, 温度低下に続く温 度上昇効果について, 筋紡錘からの求心性線維 が関与する弱い筋肉の刺激は中枢を介する減圧 反射を引きおこすため，血管の拡張を引きおこ し, 血流が増加し, 皮膚温の上昇をもたらす機 序も考えられるとしている.川喜田ら ${ }^{13)}$ は, 合谷 針通電による鎮痛効果について報告し, 鎮痛効 果は通電終了後, 刺激前值にもどるまで25～30 分が必要であり，中には60分を経ても未だ針通 電刺激前の痛みの $80 \%$ 程度にとどまっている例 もあるとしている。これは刺激後，その効果が しばらく持続するというわれわれの実験の時間 的経過と極めて一致したものであり，また一側 における針通電効果が両側に表われることから も，針鎮痛と類似の中枢性機序が働くものと考 えられる.今回の実験において, 急速輸液によ り静脈血流量, Stroke Volume, 深部体温の増 加が確認され, さらに血圧, 心拍数に大きな変 化をもたらすことなく有意な静脈血流量および Stroke Volume の増加がみられるという針通電
効果時に, $0.4 \mathrm{~m} \ell / \mathrm{kg} / \mathrm{min}$ の Haemaccel 10 分間 の急速輸液による Stroke Volume 増加とほほ同 程度の増加が得られたということは，針通電に よる末梢循環血液量の増加の要因の一つとして, まず, Stroke Volume の増加が関与する可能性 が示唆された。なお，今回統計処理に当たって は特定な分布を仮定できないため，ノンパラメ トリック (ウィルコクソンの符号付順位和検定) により検定した。

なお, 本研究は昭和 60 年度文部省科学研究費 補助金交付（課題番号60570734）によって支持 された。また，本要旨は第 5 回日本臨床麻酔学 会総会（1985年・長崎）において発表した。

稿を終わるにあたり，測定機器を提供いただ いたグッドマン社およびアステック社に深く感 謝致します。

\section{参考文献}

1) Lee DC, Lee MO, Clifford DH, et al.: Inhabition of the cardiovascular effects of acupuncture (moxibution) by propranolol in dogs during halothane anaesthesia. Canad. Anaesth. Soc. J. $23: 307-317,1976$

2 ) Sharpey-Schafer EP : Effect of respiratory acts on the circulation. In: Handbook of Physiology. Section 2: Circulation. Vol.III, Edited by Hamilton, W.F. and Dow, Phillip. American Physiological Society, Washington, D.C., 1965, p.1875-p.1886

3 ) 藤本 淳: 静脈還流。呼吸と循環 $18: 221-227,1970$

4 ）山元 博: 術中低圧系循環動態変化に関する基礎的並びに臨 床的研究. 久留米医学会雑誌 $44: 770-797,1981$

5 ) Brecher, G.A : Mechanism of venous flow under different degrees of aspiration. Amer. J. Physiol. 169 : 423-433, 1952

6) Willeput R, Rondeux C and De Troyer, A : Breathing affects venous return legs in humans. J. Appl. Physiol. $57: 971-976,1984$

7 ）森岡 亨：麻酔からみた静脈系。麻酔 $22: 727-735,1973$

8 ）阪口周吉：末梢静脈の循環動態. 呼吸と循環 $17: 664-673$, 1969

9) Almen, T. and Nylander, G. : Serial phlebography of the normal lower leg during muscular contraction and relaxation. Acta Radiol. $57: 264-272,1962$ 
10）高木健太郎，永坂鉄夫：皮店静脈の反応.生理学大系. 松 田幸次郎編。医学書院，東京，1977，p.996-p.1000

11）久住 武, 岡本途也：針通電刺激による鼻部皮唐温及び鼻閉 感の変化について.日本温泉気候物理医学会雑誌 $45: 68-75$, 1982

12) Ernst M, Lee $\mathrm{MH}$ : Sympathetic vasomotor changes induced by manual and electrical acupuncture of the Hoku point visualized by themography. Pain $21: 25-$ 33, 1985
13）川喜田健司, 岩崎友明, 岡村貞一他：針通電刺激の血圧下 降効果と鎮痛効果の比較. 岐歯学誌 $12: 13-19,1985$

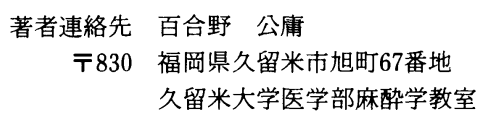

\title{
Non-invasive investigation of hemodynamic effect of electrical acupuncture on the peripheral vein in the awake human
}

\author{
Masanobu YURINO, Kazuo OHISHI, Harue MATSUOKA \\ Seiji WATANABE, Fumitaka TAYAMA and Takesuke MUTEKI \\ Department of Anesthesiology, Kurume University School of Medicine
}

In order to study the hemodynamic effect of electrical acupuncture (EAP), effects of spontaneous respiration, Valsalva, Müller maneuvers, rapid infusion and EAP on cephalic vein blood flow $\left(\mathrm{V}_{\mathrm{BF}}\right)$, bilateral palm temperature (PT), stroke volume (ST), cardiac output, heart rate and blood pressure have been investigated with non-invasive method in the non-anesthetized subjects.

$\mathrm{V}_{\mathrm{BF}}$ was decreased by inspiration, and increased by expiration. $\mathrm{V}_{\mathrm{BF}}$ and $\mathrm{PT}$ were decreased immediately after EAP stimulation and thereafter increased (mean \pm SE : 125 $\pm 39 \%$.

Besides, EAP stimulation induced an increase of impedance stroke volume (mean \pm SE : $117 \pm 6 \%$ ), and Haemaccel infusion caused an increase of impedance SV (mean \pm $\mathrm{SE}: 116 \pm 11 \%$ at the maximum].

From the above experimental results, it may be asserted that the increase in SV would be the most important factor upon an increase of peripheral blood flow due to EAP, and then the degree of the cardiovascular effect of the EAP was quantitatively evaluated to be equipotential to the volume loading due to Haemaccel infusion with the amount of 0 . $4 \mathrm{~m} \ell / \mathrm{kg} / \mathrm{min}$ for ten minutes.

The Journal of Japan Society for Clinical Anesthesia Vol. 6 No. 4, 1986 